\title{
Thamotharem and Guideline 7 of the IRB: Rethinking the Scope of the Fettering of Discretion Doctrine
}

\author{
France Houle
}

\section{Abstract}

The author examines Guideline 7 - Concerning Preparation and Conduct of a Hearing in the Refugee Protection Division of the Immigration and Refugee Board. She critiques the use of the fettering of discretion doctrine when it is applied to procedural guidelines. She argues that it is based on a false ontology about the nature of rules and guidelines. She also critiques the use of the fettering of independence doctrine when applied to procedural guidelines aimed at enhancing the expediency, rather than consistency, of decision making. Her main argument is that Guideline 7 does not impede, per se, the ability of RPD members to decide according to their own conscience and opinion.

\section{Résumé}

Lauteure examine la Directive 7 - Concernant la préparation et la conduite d'audience devant la Division de la protection des réfugiés. Elle critique l'usage de la doctrine de l'entrave à la discrétion lorsquelle est appliquée à des directives procédurales. Elle argumente qu'elle est basée sur une fausse ontologie sur la nature des règles et des directives. Elle critique aussi l'usage de la doctrine de l'entrave à l'indépendance lorsqu'elle est appliquée à des directives procédurales qui ont pour fonction d'accroître la célérité, plutôt que la cohérence, du processus décisionnel. Son principal argument est que la Directive 7 n'affecte pas, en soi, la capacité des membres du tribunal de décider selon leur conscience et opinion.

\section{Introduction}

Few purely adjudicative administrative tribunals use policy instruments such as guidelines to confine or structure their board members' discretion. The main concern with the use of such instruments is that they may negatively interfere with independence and impartiality of decision makers. But not all administrative tribunals share this concern. In Canada, the Immigration and Refugee Board (IRB or Board) has been very creative in its usage of a variety of policy instruments since its inception in 1989. Besides four sets of rules of procedure and practice, the Chairperson has issued eight guidelines, two jurisprudential guides, six persuasive decisions, thirteen policies, two instructions, and nine policy notes. ${ }^{1}$ In this paper, I will examine one of the IRB's guidelines: Guideline 7 - Concerning Preparation and Conduct of a Hearing in the Refugee Protection Division (Guideline 7). ${ }^{2}$ The reason for studying this guideline is because it is one of the most controversial policy instruments issued by the IRB. Although its validity was challenged in courts and the Federal Court of Appeal resolved the litigation in 2007 in favour of the IRB, this guideline is still the subject of much discussion in refugee circles.

Guideline 7 is a case management policy instrument. It is a procedural guideline which aims to enhance the expediency of the decision-making process of the Refugee Protection Division (RPD). As stated by the IRB in the text of Guideline 7 , its main purpose is to make the best use of hearing time by the RPD. In fact, the IRB was, and still is, very preoccupied with the backlog of refugee claims. It has been a major problem for the Board since its early days and Guideline 7 is one of the tools which is part of the IRB action plan to increase the Board's efficiency in this regard. ${ }^{3}$

Section 3 of Guideline 7 contains the guideline at the heart of litigation. Paragraph 19 changes the order of questioning by having the RPD leading the inquiry in the hearing room:

In a claim for refugee protection, the standard practice will be for the RPO [Refugee Protection Officer ${ }^{4}$ ] to start questioning the claimant. If there is no RPO participating in the hearing, the member will begin, followed by counsel for the claimant. Beginning the hearing in this way allows the claimant to quickly understand what evidence the member 
needs from the claimant in order for the claimant to prove his or her case.

This new procedure has come to be known as "reverse order questioning." It is now the standard practice in front of the RPD. With this new procedural setting, claims are processed in the following manner: The RPD member assigned to a case makes a preliminary identification of the issues she considers to be problematic and central to the claim. This identification is based on the information disclosed by the claimant in his Personal Information Form. ${ }^{5}$ Thereafter, the RPD member is required to fill in a File Screening Form identifying those issues in writing and to provide a copy of the form to the claimant with the notice to appear. At the hearing, the RPD (member or RPO) will start questioning the claimant on those issues identified in the File Screening Form, after which the claimant will be given the possibility of completing or correcting his answers to the questions previously asked by the RPD. In sum, the claimant can no longer tell his whole story during the hearing, unless he is successful in his application to vary the order of questioning under paragraph 23 of Guideline $7 .{ }^{6}$ When an application to vary the order is allowed, the hearing will proceed the way it used to in most cases before Guideline 7 was issued. A claimant will present his case first and be questioned thereafter by the RPD.

Although Guideline 7 became operational on 1 December 2003, paragraph 19 became effective only on 1 June 2004, and from this date until 25 May 2007, Toronto-based claimants (for the most part) objected to the reverse order questioning procedure. Their view was that Guideline 7 was invalid because it violated the principles of procedural fairness and fettered RPD members' discretion. During this period of time, RPD members usually rejected this objection until several counsels for claimants decided to challenge the validity of these RPD decisions and Guideline 7 in front of the Federal Court. In 2006, two contradictory decisions emerged: Thamotharem ${ }^{7}$ and Benitez. ${ }^{8}$

In January 2006, Mr. Thamotharem's application for judicial review was granted by Justice Blanchard of the Federal Court, who quashed the RPD's decision on the basis that Guideline 7 was an invalid fetter on the RPD members' discretion in the conduct of the hearing. However, Justice Blanchard rejected the applicant's allegation that Guideline 7 violated the principles of procedural fairness. In April 2006, Mr. Benitez's application for judicial review was dismissed by Justice Mosley of the Federal Court. Justice Mosley agreed with Blanchard J. that Guideline 7 did not violate the principles of natural justice, but he disagreed with his colleague on the issue that Guideline 7 fettered Board members' discretion. Both decisions were appealed to the Federal Court of Appeal. Justice Evans dismissed the appeals. ${ }^{9}$ According to his ruling,
Guideline 7 did not violate the principles of natural justice nor did it fetter RPD members' discretion in the conduct of the hearing. Applications for leave to appeal to the Supreme Court were filed and dismissed on 13 December 2007.10

Of the two main issues raised in both levels of courts, I will focus on examining the reasons on the fettering of discretion doctrine. I will focus on this issue because the legal parameters surrounding the power of public authorities, and administrative tribunals in particular, to issue guidelines and other policy instruments are underdeveloped in administrative law. Most notably, there is very little nuance in case law between the nature and purpose of guidelines which results in a linear application of the fettering of discretion doctrine to all guidelines without distinction. This is precisely the issue that this paper addresses. But before discussing it in more detail, it is necessary to briefly explain the problems raised by the fettering of discretion doctrine.

\section{Fettering of Discretion Doctrine}

The doctrine of fettering discretion tackles a classical problem in administrative law concerning the scope of discretionary powers. More precisely, the doctrine fixes the outer boundary of what a public authority ought not to do when exercising its discretionary powers. It ought not to transform its power to choose to exercise discretion in a particular way into a duty to compel a decision maker to exercise his discretion in a particular way.

The idea that a guideline cannot be mandatory is closely linked to a concept of legal norms: that there is a sharp distinction between "rules" and "discretion." Rules regulate the conduct of individuals and are enforced by public authorities. Legal rules are characterized as hard and mandatory. Their validity is assessed through the lenses of their conformity with the legal powers to make delegated legislation granted to that authority: "Is the rule intra or ultra vires?" This is a question engaging an interpretative exercise.

Discretionary powers are understood as the antithesis to rules as public authorities are entitled to make choices to determine the best course of action on a case-by-case basis. Contrary to rules, discretionary powers are characterized as soft and flexible. Unlike rule-making powers, discretionary powers are conferred with a variable, yet relative, degree of broadness, which makes the interpretation of their scope a far more difficult and fuzzy exercise to accomplish, with uncertain results on the excess of jurisdiction ground of review. Therefore, and more often than not, when public authorities exercise their discretion, the validity of their actions is assessed, not under the excess of jurisdiction ground of review, but under specific grounds better adapted to this type of power and classified under "abuse of discretionary powers." Under this ground, the judicial inquiry focuses on the 
facts identified by public authorities to exercise their judgment. Discretion is abused when, for example, its exercise is based on improper purposes, irrelevant considerations, or bad faith.

However, as D. Mullan points out, as well as the Supreme Court in Baker, there "is no bright line distinction between exercising discretion and engaging in interpretation." 11 This statement is even truer when the validity of guidelines is under scrutiny for they are issued to put some normative constraints on the exercise of discretion. From this perspective, "rules" and "guidelines" share common characteristics which, in turn, raise the question of statutory jurisdiction to issue norms in the form of guidelines. But again, the interpretative exercise can often be inconclusive as guidelines do not need to be explicitly authorized by statute. ${ }^{12}$

In the legal literature, Carver wrote a paper entirely dedicated to Thamotharem and Benitez and discussed the problem of statutory jurisdiction to issue guidelines by asking the following question: ${ }^{13}$ What is the legal significance of statutory authorization of non-binding guidelines? To answer his question, Carver points out firstly that s. 159(1) (h) of the IRPA confers to the Chairperson of the Board the power to issue guidelines to assist members in carrying out their duties. To his view, this power "appears to express the clear intention of Parliament to enhance the power of the IRB Chairperson to direct the Board's adjudicative activities." However, he further argues that this does not necessarily equate to a power to make subordinate legislation. This is correct, and in fact this interpretation is foreclosed by the IRPA. Indeed, s. 93 expressly states that: "[ ... ] guidelines issued by the Chairperson under paragraph 159(1)(h) are not statutory instruments for the purposes of the Statutory Instruments Act." Nonetheless, his question is important because the Supreme Court decided in 1978 in Capital Cities Communications that administrative tribunals have an implied authority to adopt non-binding policy statements. ${ }^{14}$ However, because this decision was taken in the context of a policy statement adopted by a regulatory agency, that is to say the CRTC, the issue remains open as to whether all types of administrative tribunals should, on the one hand, be recognized with implied authority to adopt policy statements. I will examine this point in part 3 of this paper.

On the other hand, when no explicit statutory authority is required, the guideline will be deemed valid as long as there is no obvious incompatibility between the guideline and the statute. One obvious incompatibility that has been sanctioned by courts is when a guideline prescribes a conduct to Board members, rather than providing guides to assist them in their exercise of a discretionary power. It is in this context that the doctrine of fettering of discretion was developed as a subclass of "abuse of discretionary powers" ground of review.

The fettering of discretion doctrine has been used primarily to assess the validity of policy instruments such as guidelines. ${ }^{15}$ Judges examine whether Board members can exercise their discretion in each matter coming before them. The exercise of discretion must not be "determined automatically or fettered by a rigid policy laid down in advance." 16

My main critique of this doctrine is that it is based on a false ontology about the nature of rules and guidelines. A very significant number of legal rules do not directly affect the rights and interests of individuals but confine and structure the powers granted to public authorities. In addition, many legal rules are not imperative (mandatory), but permissive and conditional (flexible). This is especially true in the case of procedural rules because most of them have to provide space for the principles of natural justice to operate effectively. It is for this reason that the line between a procedural rule and a procedural guideline is too often blurred to support a convincing argument based on the fettering of discretion doctrine unless, of course, a Board makes the obvious mistake of using imperative language in the text of the guideline, or any other markers, ${ }^{17}$ showing that the Board clearly intended to leave no measure of meaningful discretion to be exercised by its decision makers. Presumably, the public administration now knows how to write its guidelines to meet the requirements of case law.

It is not at all clear that the fettering of discretion doctrine is helpful or adapted to especially examine the validity of procedural guidelines. The general question I am raising is whether an inquiry focusing on the mandatory character of a procedural guideline sheds light on an artificial problem, while obscuring real ones; problems that would be virtually impossible to bring to the surface because of the very framework of analysis imposed by this doctrine. This issue is related to the second question asked by P. Carver in his paper: Are guidelines dealing with issues of hearing process more problematic than guidelines addressing substantive issues? His answer to this question is that it "seems less appropriate to issue a guideline going to procedure than to substantive considerations." I disagree with this statement and I will develop my arguments to support my position in part 3 of this paper. Finally, in relation to this issue, Carver notes that there is a " $[\ldots]$ discomfort with the combining in Thamotharem and Benitez of an analysis of 'fettering discretion' with that of 'procedural justice"' because these concepts do not cover the same territory. ${ }^{18}$ I agree with Carver and the next section is mainly dedicated to the kinds of legal discomforts that this ground of review raises, especially when applied to a procedural guideline. 
As the case law evolves, however, there are some signs that the examination of the validity of a guideline, especially of a procedural guideline, is developing beyond a strict understanding of the fettering of discretion doctrine, to allow for a much deeper examination of the diversity in nature and purposes of guidelines. This may in turn trigger the development of a more complete framework of analysis aimed at assessing the validity of policy instruments, focusing on the interpretation of the enabling statute as a whole in order to verify the compatibility of a guideline with the statute of which it purports to increase the effectiveness. From this perspective, I will examine in part 4 the compatibility of Guideline 7 with the IRPA.

\section{Two Distinct Analytical Perspectives}

In order to be successful in court in proving that a guideline is invalid, a party must demonstrate that it leaves no measure of meaningful discretion to be exercised by the public authority; in other words, the guideline is binding on the decision makers. The validity of a guideline can be challenged on two grounds of review: the lack of jurisdiction of the Board to issue the guideline and the violation of the principles of natural justice. Arguments on each ground can be developed from two separate perspectives: instrumental and institutional. These perspectives are encapsulated in the three criteria which were set by the Ainsley decision and applied by the judges of the Federal Court and the Federal Court of Appeal in Thamotharem and Benitez to analyze the validity of Guideline 7: (1) the language of the policy, including its application on a case-by-case basis; (2) the practical effect of failing to comply with the policy; and (3) the evidence with respect to the expectations of the Commission and staff regarding the implementation of the policy instrument. ${ }^{19}$

First, a party may attempt to show that the language used in the guideline is mandatory and that, in practice, the guideline is applied by decision makers as if it were binding (criterion no. 1 of the Ainsley decision). I call this inquiry "instrumental" because it focuses on the guideline itself to determine if decision makers use this instrument not as a flexible but as a mandatory normative tool. Second, a party may attempt to show that there are institutional pressures such that decision makers feel obliged to apply the guideline. The inquiry will focus on the effect of a decision maker failing to comply with the guideline as well as the expectations of the Chairperson of the tribunal regarding its implementation (criteria no. 2 and no. 3 of the Ainsley decision). I call this inquiry "institutional" because it does not focus on the guideline itself, but on decision makers and the environment in which they work.

I will first review the Court's analysis of criterion no. 1 from the instrumental perspective. Second, I will examine the distinction between the application of criteria no. 2 and no. 3 when analyzed from the instrumental perspective and from the institutional perspective. I will argue that the instrumental perspective not only lacks relevancy to analyze a procedural guideline, but it also requires parties to gather evidence that is very difficult to collect. With the institutional line of inquiry, the examination of the validity of a procedural guideline is connected to the violation of the principles of natural justice. This analytical framework may prove to be more appropriate to assess the validity of guidelines depending on the purpose of the very guideline under scrutiny.

\subsection{Instrumental Perspective}

As said earlier, the foundation of the instrumental perspective is based on the premise that there is an ontological distinction between a rule and a guideline. According to the Ainsley decision, a guideline will be found invalid if it crosses "the Rubicon between a non-mandatory guideline and a mandatory pronouncement having the same effect as a statutory instrument." 20

This view is mainly encapsulated in the Ainsley analysis of the language and the application of a guideline (criterion no. 1). On this issue, the analysis of the Federal Court in Thamotharem and Benitez turned around two arguments. First, the question was whether or not the use of the verbs in the passage "the standard practice will be for the RPO to begin and if no RPO is participating at the hearing, the Board member will begin" is an indication of the mandatory character of the Guideline 7. The second argument was built on paragraph 23 of the guideline, which allows for the Board member to vary the order of questioning. The question was whether the wording of paragraph 23 was sufficiently flexible or whether the threshold was set too high. As written in Guideline 7, the order of questioning can be varied by a RPD member only in cases constituting exceptional circumstances, that is to say, only when claimants are severely disturbed or when a child is very young. ${ }^{21}$ The two justices of the Federal Court approached the problem from different angles. Blanchard J. focused his analysis on the language of the guideline, while Mosley J. examined the evidence regarding its application by RPD members.

In Thamotharem, Justice Blanchard expressed the opinion that "viewed in its entirety, the language of Guideline 7 leaves little doubt that the thrust of the guideline indicates to Board members a mandatory process rather than a recommended but optional process [ ... ] is imperative." ${ }^{22}$ In Benitez, Justice Mosley examined the evidence presented by the Board showing that RPD members have exercised their discretion to vary the order of questioning. Some forty decisions and excerpts of transcripts from hearings before various RPD members 
were filed as new evidence in the Court's record. This evidence satisfied Justice Mosley that RPD members can choose to disregard the standard practice when they deemed it necessary. ${ }^{23}$

Justice Evans disagreed with both judges as to the manner in which the problem should be analyzed. He disagreed with Justice Mosley insofar as he was of the view that there should not be much if any significance attached to the differences in the records. ${ }^{24}$ From Justice Evans's perspective, a judge should pay more attention to the language of a guideline than to the evidence regarding its application, because it "is inherently difficult to predict how decision makers will apply a guideline, especially in an agency, like the Board, with a large membership sitting in panels." ${ }^{25}$ I agree with Justice Evans's opinion. From the perspective of the individual attempting to show the invalidity of a guideline, bringing clear evidence that the guideline is routinely applied as if it were mandatory is a highly difficult task. Many obstacles prevent outsiders from assembling this type of evidence. ${ }^{26}$

With respect to the language used in the text of a guideline, Justice Evans disagreed partly with the analysis of Justice Blanchard in Thamotharem. Even if both shared the view that Guideline 7 was imposing more than a "recommended but optional process,", Justice Evans stated that it was perfectly valid for a Board to establish how discretion would "normally" [Evans J. emphasis] be exercised as long as a "decision-maker may deviate from normal practice in the light of particular facts." 27 Here, Justice Evans indicated clearly that, unless there is explicit language showing the mandatory character of a guideline, all other signs indicating normative constraints on the exercise of Board members' discretion will be deemed valid. ${ }^{28}$

In this sense, Justice Evans recognized the existence of a continuum in (or a degree of) normativity: "legal rules and discretion do not inhabit different universes, but are arrayed along a continuum." 29 This view is in not only in accord with the diversity of legal norms found in statutes and regulations in contemporary public law, but also with the Board's usage of guidelines. The IRB is a very good example to show the case at point. When one looks at the policy instruments issued by the IRB, it becomes clear that, as a matter of fact, the IRB conceptualizes the mandatory character of its policy instruments in terms of degrees:

There is no doubt that, save for the "persuasive decisions," all the policy instruments of the IRB are not optional for the Board members. They are meant to regulate their conduct during proceedings, either in a substantive or in a procedural manner, and in a more or less constraining fashion depending on how quickly the problem perceived by the IRB should be solved. Indeed, the Chairperson's instructions are clearly imperative.
This diversity of policy instruments issued by the IRB is an eloquent testimony to the complexity of contemporary legal systems: they are not composed solely of formal sources of norms that we recognized as "law," but also of informal (explicit and implicit) norms. ${ }^{30}$ It is suggested that it is from this perspective that courts have (or should have) recognized that boards are permitted to issue a broad range of guidelines without needing an explicit grant of statutory power. Indeed, policy instruments may often be the only viable solution to solve daily problems that boards encounter in their daily functioning.

With respect to the specific problem of the mandatory character of a procedural guideline, the following question will provide the basis for the analysis: is it accurate that all procedural guidelines can never be mandatory? In my view, some procedural guidelines can be. The obvious example is that, when Parliament grants a power to a public authority to issue mandatory procedural guidelines, they will be valid and can "no more be characterized as an unlawful fetter on members' exercise of discretion." ${ }^{31}$ In the case of Guideline 7, it is clear as Justice Evans pointed out in Thamotharem that Parliament has not authorized the IRB to issue mandatory guidelines. Section 159(1)(h) entitles the Chairperson to issue guidelines to assist members in the conduct of their duties and not to prescribe to them how to conduct their duties. However, in my opinion, s. 159(1) $(h)$ of the IRPA does not preclude the possibility of issuing mandatory procedural guidelines. Two situations come to mind.

First, when a tribunal codifies well-established common law principles of natural justice, the guideline can take a mandatory form (for example, when case law would clearly state that claimants of a given category have a right to counsel). In this specific case, the guideline would simply codify positive law. Second, it can also be suggested that absent case law, it would be perfectly legal for a tribunal to issue guidelines which would confer greater or clearer procedural protection to claimants (and therefore prefer to resort to a statement of policy applicable across the board, than to the case-by-case incremental technique to implement changes). ${ }^{32}$ Beside these two scenarios, guidelines must be drafted to ensure that the principles of procedural justice will operate effectively in the legal system in which they are applied.

One final issue is related to the proper field of jurisdiction between rule-making authority and policy-making authority. This question was discussed by Justice Evans in Thamotharem because in addition to the policy-making power conferred on the IRB by s. 159(1) $(h)$ of the IRPA, s. 161(1)(a) of the Act also grants to the Board the power to make rules of practice and procedure. The questions asked were: Is there an exclusive domain for rules? If yes, what type of norms is comprised in it? If this field does not encom- 
Figure 1. IRB Guidelines/Mandatory Index

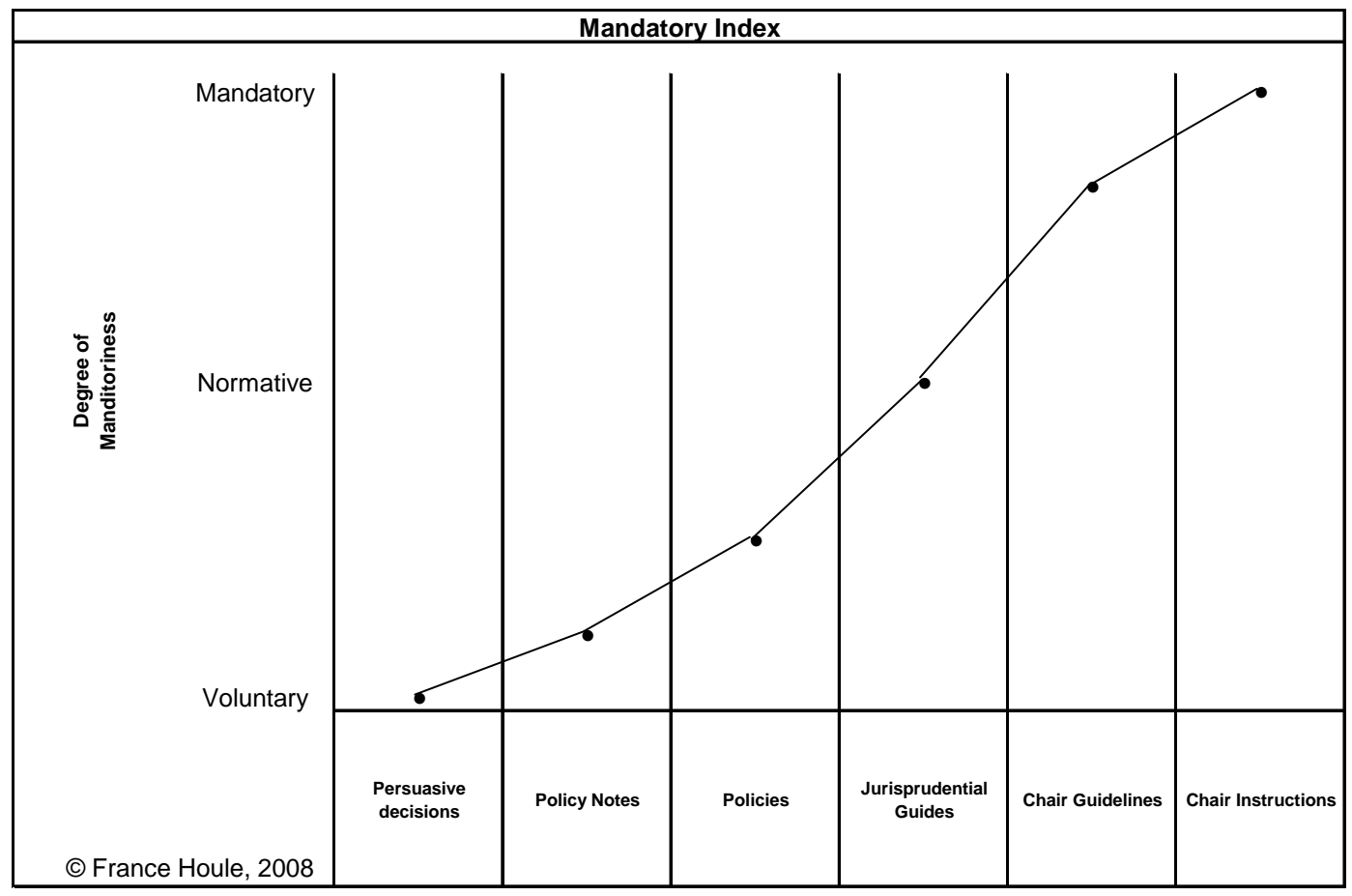

Note: This figure was made by the author from the description of each policy instrument provided by the IRB on its website, <http:// www.irb-cisr.gc.ca/en/references/policy/rules/index_e.htm>. Here is a summary: Persuasive decisions: Unlike Jurisprudential Guides, decision makers are not required to explain their decision to not apply a persuasive decision in appropriate circumstances. Their application is voluntary. Policies are flexible instruments, and the degree to which they are mandatory varies with the content of the policy. They often contain elements which are mandatory, but may also provide general guidance or define areas in which the exercise of discretion is required; Policy notes are memoranda which serve as an informal way of providing policy guidance. Jurisprudential guides: The application of a Jurisprudential Guide is not mandatory. However, decision makers are expected to apply Jurisprudential Guides in cases with similar facts or provide reasoned justifications for not doing so. Chairperson's guidelines: While they are not mandatory, decision makers are expected to apply them or provide a reasoned justification for not doing so. Chairperson's Instructions provide formal direction that obliges specific IRB personnel to take or to avoid specific actions.

pass all the rules, do rule-making and policy-making powers overlap, and if yes, to what extent? Justice Evans expressed the general view that guidelines and rules do not have the same legal effects, while recognizing that the two can overlap. ${ }^{33}$ As Justice Evans observed, the differences in the legal characteristics of statutory rules of procedure and Guideline 7 should not be overstated. ${ }^{34}$

In order to bring some precision to Justice Evans's view, it is interesting to look closely at the RPD rules of practice and procedure. Refugee Protection Division Rules can be divided into two categories, each comprised of roughly 50 per cent of all rules: those addressed directly to claimants and those addressed directly to RPD members ${ }^{35}$ Of the 50 per cent of rules speaking directly to refugee claimants and the Minister of Citizenship and Immigration around 40 per cent of them do so in mandatory language ("must"). Since these rules impose practice and procedure duties on the parties, the Division had no choice but to proceed through a legislative instrument. This is one specific field reserved to legislation (primary and subordinate). Indeed, legal norms affecting rights and obligations of individuals must be stated in statutes or regulations.

The other 50 per cent of rules speak to RPD members (or $\mathrm{RPO}$ ). Only around 10 per cent of rules are mandatory for Members and RPOs ("must"). However, for the vast majority of these rules, they codify common law principles (notice to appear, notice of decision, notice prior to the use of specialized knowledge) protective of claimants' rights and interests. As for the remaining 40 per cent of rules, they either give broad discretion to Board members or some meaningful dis- 
cretion to exercise to determine procedural issues. As said earlier, policy instruments can also be used to achieve these two same results. As a consequence, one must conclude that, as far as norms speaking directly to the RPD are concerned, there is no striking difference between procedural rules and procedural guidelines. This entire field can overlap. However, if a guideline conflicts with a rule, the latter will prevail. ${ }^{36}$

When examining the validity of a procedural guideline, the question related to their mandatory character does not appear to be as significant as in the case of substantive guidelines. On this point, it is interesting to note that Justice Evans did not seem to attach so much importance to this factor in Thamotharem when he analyzed the question whether Guideline 7 was a fetter on RPD members' discretion. As he wrote: a policy instrument "must not be so coercive as to raise a reasonable apprehension that members' ability to decide cases free from improper constraints has been undermined." 37 The words used by Justice Evans are important because, as far as procedural policy instruments are concerned, it is possible to impose a fairly high level of constraints on decision makers when the problem to be solved warrants it. Indeed, his analysis of the constraints imposed on RPD members is revealing in this respect. As long as they serve the "legitimate interest" of the IRB, he does not find them "at all sinister," 38 notably given the fact the IRB is the "largest administrative agency in Canada" where hearings are conducted "mostly by single members." 39

In sum, the inquiry into the mandatory character of a guideline might be sufficient in some cases, for example, when a policy instrument speaks directly to persons and affects their rights and interests. On this point, it is important to note that Justice Evans cautioned judges on the use of the Ainsley criteria to examine all types of guidelines, for the policy statement that was considered in that case affected directly the rights and interests of businesses and thus more clearly bore the mark of a "rule." 40

However, when a policy speaks directly to public authorities (such as Guideline 7, which is directed at the practice of RPD members by laying down the standard conduct that is expected from RPD members), this inquiry into the mandatory character of a policy instrument is bound to have less impact in contemporary administrative law. Indeed, from Maple Lodge and Thamotharem, we know that a guideline can have a normative effect (that is to say that it can regulate the conduct of public authorities) and that having a normative effect does not automatically mean that the guideline is mandatory and, therefore, invalid. In fact, it can be concluded from these judgments that the fettering of discretion doctrine can be clearly and easily applied to the seldom truly mandatory substantive guidelines. All other cases involving other normative guidelines would require clear evidence that the guideline fetters the discretion of decision makers. As said earlier, bringing such evidence to a court is a very difficult and complex task for a party contesting the validity of a guideline, if not impossible in the case of the IRB.

The instrumental perspective offers a superficial understanding of guidelines. It aims at targeting the most offensive guidelines (and especially those directly affecting the rights and interests of the persons). It does not allow for a deeper analysis of the effect of the guideline on the legislative design and on the role of the various actors into the legal system in which a guideline operates. Presumably for this reason, Justice Evans quickly moved away from a strict instrumental perspective to adopt an institutional perspective to examine the validity of Guideline 7 .

\subsection{Institutional Perspective}

From an institutional perspective, guidelines are examined with the view to understand their role both in the operational environment of a board and more precisely in the legal environment set by statute to protect the independence of decision makers. In the context of an administrative tribunal, the institutional perspective recognizes that there can be internal tensions between the objectives of the institution per se (personified by the chairperson) and those of tribunal members. Criteria no. 2 and no. 3 of the Ainsley decision (the effects of failing to comply with the guideline for a board member and the expectations of a board with respect to the implementation of a guideline) aim at encapsulating this inner tension within a board. However, the development of the institutional perspective did not start in Ainsley, but in Consolidated-Bathurst of the Supreme Court. ${ }^{41}$

Although Ainsley was decided in 1994, Justice Doherty made no reference to Consolidated-Bathurst in her judgment. There are at least two reasons for which these two decisions remained disconnected. First, Ainsley concerned substantive guidelines while Consolidated-Bathurst concerned procedural guidelines (to be more accurate, a procedural practice). Second, the ground of review to contest the procedure of full board meetings in Consolidated-Bathurst was a breach of the rules of natural justice. The appellant's main argument against the practice of holding full board meetings was that these meetings can be used to fetter the independence of the panel members. For obvious reasons, this ground of review could not have been argued in Ainsley for it concerned substantive guidelines.

Nevertheless, judges used criteria no. 2 and no. 3 in Thamotharem and Benitez, and referred to Ainsley and Consolidated-Bathurst, either to determine if a public authority has jurisdiction to issue the impugned guideline (Ainsley) or to determine if the procedure violates the principles of natural justice (Consolidated-Bathurst). My claim is that applying 
the Ainsley criteria no. 2 and no. 3 to a procedural guideline, such as Guideline 7, to determine if a board has jurisdiction to issue that guideline raises questions as to the usefulness of such an inquiry. Indeed, a party contesting a procedural guideline, such as Guideline 7, must bring clear evidence based on criteria no. 2 and no. 3 to show that it fetters RPD members' discretion, meaning here that it prevents the principles of natural justice to operate effectively in the decision-making process of this Board. As the analyses of Justices Blanchard and Mosley showed in Thamotharem and Benitez, this inquiry did not lead to very conclusive results.

In Thamotharem, Justice Blanchard first stated that he was not convinced that the monitoring exercise conducted by the IRB could be said "to be inappropriate or, on its own, constitute a clear indicator of fettering of a Board member's discretion," 42 but then he moved on and wrote that he was "satisfied that there [was] significant evidence that the IRB made known to its members that they are expected to comply with the guideline save in exceptional cases." ${ }^{33}$ In Benitez, Justice Mosley reached a completely different conclusion on this point. He found that there was no evidence on the record to suggest that the Chairperson "has threatened to, or has in fact, sanctioned any Board member for non-compliance with Guideline 7."44 Thereafter, Justice Mosley found that there was evidence that monitoring procedures were voluntary and that "even if RPD members were asked to explain why they did not follow the guideline," there was "no evidence of any consequences flowing to those who chose to ignore or to not strictly apply them." ${ }^{45}$ This line of inquiry does not lead to a relevant answer to the question as to whether the principles of natural justice can still operate effectively in the refugee determination process. ${ }^{46}$

Presumably, Justice Evans saw the problem and, for this reason, he decided to focus his analysis on the question as to whether Guideline 7 fettered RPD members' independence and impartiality. By this, he clearly shifted the analysis to the terrain of the violation of the principles of natural justice, following the path traced by the Supreme Court in ConsolidatedBathurst. This was an interesting move because it expands the application of Consolidated-Bathurst (Tremblay and Ellis Don) to all types of procedural policy instruments, rather than keeping it to the confines of full board meetings. Moreover, and more specifically in the context of the evolution of the case law pertaining to independence of administrative tribunal, Justice Evans also invites judges to show greater awareness in the protection of tribunals' sphere of adjudication. However, and as Evans J. rightly pointed out, adjudicative independence "is not an all or nothing thing, but it is a question of degree." ${ }^{47}$ On this point, Justice Evans found that Guideline 7 does not create the kind of coercive environment which unduly constrains Board members' independence. ${ }^{48}$
Next, I will explore Justice Evans's reasons on this argument in more detail. For the moment, suffice it to say that I believe his view about the degree of influence that a guideline may exert on a board member to decide according to their own conscience and opinion is relevant depending on the nature and purpose of the guideline under review. On this point, it is not all that clear that this line of inquiry was relevant in the case of a procedural guideline, such as Guideline 7.

\section{Nature and Purpose of a Guideline}

In starting the discussion on the effect of Guideline 7 on the independence and impartiality of RPD members, Justice Evans recalled the basic principle that decision makers "must perform their adjudicative functions without improper influence from others, including the Chairperson and other members of the Board." 49 Thus, the discussion is framed in a specific context, that of a decentralized agency conferred with adjudicative powers. The degree of independence conferred on administrative tribunals in general varies depending on several factors. ${ }^{50}$ I will not review the factors here. Suffice it to say that case law recognizes that a purely adjudicative tribunal such as the RPD, the decisions of which affect fundamental rights, is entitled to a high degree of independence. ${ }^{51}$ The consequence flowing from this finding is two-fold.

First, it is not a given that such tribunals should be recognized with implicit powers to issue substantive as well as procedural guidelines. My claim is that both types of guidelines raise completely different legal problems with respect to independence of Board members. Substantive guidelines cannot be issued by purely administrative tribunals, for they raise a constitutional law problem. ${ }^{52}$ Procedural guidelines can be based on implicit powers and their validity raises an administrative law problem. However, this question was not at issue in Thamotharem insofar as Guideline 7 is a procedural guideline and also because Justice Evans stated that section $159(1)(h)$ of the IRPA entitles the Chairperson to issue substantive as well as procedural guidelines. ${ }^{53}$

Nevertheless, the question that s. 159(1) (h) raises is whether it matters to distinguish between substance and procedure to determine if a guideline fetters the independence and impartiality of purely adjudicative tribunals, such as the RPD. My answer to this question is that it does. My claim is that the analysis of the mandatory character of a substantive guideline can be fairly straightforward. If a judge finds that such a guideline is mandatory in the sense that it leaves no measure of meaningful discretion to be exercised by decision maker, it could be found invalid on the fettering of discretion doctrine. However, in the case of a procedural guideline, the analysis of the mandatory character is more complex and answers should be more nuanced. This question will be examined first. 
Second, Justice Evans also added that the principle of independence can be tempered insofar as the jurisprudence recognized that "administrative agencies must be free to devise processes for ensuring an acceptable level of consistency and quality in their decisions." 54 This sentence encapsulates another important question for the examination of the validity of a policy instrument: the purpose of the tool. Justice Evans speaks of procedural tools aiming at fostering consistency. I agree with Justice Evans that when policy instruments aim at fostering consistency, it is very relevant to conduct an analysis within the framework of independence and impartiality. However, I disagree with Justice Evans when he writes that Guideline 7 is a tool that was created by the IRB to enhance consistency. The primary purpose of Guideline 7 is to foster expediency of decision making by RPD members. In my view, when such a purpose is assigned to a procedural guideline, it is questionable whether the independence and impartiality framework of analysis is helpful to reach conclusive findings with respect to the validity of such a guideline.

\subsection{Substance and Procedure}

Substantive and procedural policy instruments may exert different degrees of influence on decision makers. The basic legal framework created for purely adjudicative tribunals by Parliament confers a different degree of autonomy on these tribunals to determine issues of substance and of procedure. Thus, the analysis of the validity of substantive and procedural guidelines cannot be conducted within the same legal parameters, even if, in both cases, these policy instruments are issued to exercise some normative constraints on decision makers. However, the constraints should be proportionate to a meaningful preservation of the integrity of the powers granted to decision makers by the statutory framework.

It is not at all clear that a purely adjudicative tribunal is entitled to issue substantive guidelines, unless it is explicitly authorized by statute. One important reason militates in favour of this view: substantive guidelines are not compatible with the statutory mandate conferred by Parliament on this type of tribunal. Indeed, purely adjudicative tribunals do not have powers to make substantive regulations conferred on them, unlike regulatory agencies, the role of which is to regulate specific economic activities. Purely adjudicative tribunals are not entitled to change, modify, or adjust the application of statutory provisions through norms of general application of their own making. The only tool available to them is interpretation, insofar as one accepts the view that interpretation does have, through the passage of time, the effect of modifying the statute.

Decision makers' role in a purely adjudicative tribunal is to adhere to the views of Parliament as expressed in their governing statute, and not to the views of the government of the day nor to those of the Chairperson (contrary to regulatory agencies where both public authorities can exercise far more leadership through either guidelines, orders, or regulations). Therefore, purely adjudicative tribunals have little substantive autonomy when compared to other decentralized agencies. In this context, the examination of the mandatory character of a guideline should be strictly conducted because the distinction between "mandatory" and "permissive" guidelines matters a great deal. Mandatory guidelines would clearly constitute an excess of jurisdiction when issued by purely adjudicative tribunals, unless Parliament has expressly authorized a particular tribunal to resort to such mandatory policy instruments.

Moreover, the Chairperson of a purely adjudicative tribunal should be very careful in drafting substantive guidelines to ensure that he or she leaves sufficient room to decision makers to interpret the statute as they see fit given the facts of a case. Substantive guidelines must preserve the integrity of the substantive adjudicative power conferred upon them by Parliament and the normative constraints they impose on decision makers should be kept to a minimum. Judges should not hesitate to interfere when the content of a substantive guideline is not compatible with these parameters. An example of a good practice in this regard is the IRB. The Chairperson of the IRB was successful in devising substantive guidelines respectful of the independence of its members and to preserve their interpretative sphere of autonomy conferred by the IRPA. For example, Guidelines 4 provide a framework of analysis to guide members when they determine specific substantive issues. ${ }^{55}$

When examining the validity of procedural guidelines, two general questions should be discussed separately: first, the degree of autonomy of purely adjudicative tribunals with respect to procedural questions; second, the appropriate and valid degree of mandatory character of guidelines.

With respect to the degree of autonomy, it has long been a principle of administrative law that administrative tribunals are masters of their own procedure. Decision makers do not need explicit statutory powers to determine how cases will proceed in front of them. Therefore, the problem of formal legality (in the sense that a specific grant of power must be given in a statute) is irrelevant insofar as the procedure is compatible with the process established by Parliament. As a consequence, whether decision makers make procedural choices incrementally or through procedural guidelines (or through rules when the statute authorizes the use of this instrument) does not matter as long as their procedural decisions do not violate the principles of natural justice.

Whatever the procedural tool used by a tribunal, the principles of natural justice must be able to operate to ensure meaningful protection to parties of their right to be heard 
by an impartial tribunal, or, at the very least, have a neutral effect on these protections (assuming that such as neutral effect is indeed possible). Therefore, the question of the validity of a guideline must be looked at from a concrete perspective (What is the effect of Guideline 7 on the right to be heard by an impartial tribunal of refugee claimants?), rather than an abstract perspective (Does the guideline leave a meaningful measure of discretion to be exercised?). With respect to Guideline 7, that is to say, to a procedural guideline aiming at fostering expediency, this concrete perspective is encapsulated in section 162(2) of the IRPA: "Each Division shall deal with all proceedings before it as informally and quickly as the circumstances and the considerations of fairness and natural justice permit."

With respect to the appropriate and valid degree of mandatory character of procedural guidelines, it is important to recall that its function in the decision making process of a board is of primary importance. As pointed out earlier, a guideline can take a mandatory form when its function is simply to codify positive law, or to confer greater or clearer procedural protection to claimants. Outside these two scenarios, the inquiry should focus on the question as to whether a procedural guideline leaves sufficient discretion to Board members to ensure that the principles of natural justice can operate effectively in the legal system in which it is applied. In other words, a board member must be able to determine what participatory rights to the procedure would be fair to grant to a claimant, given her requests for procedural protection in a given situation, and to decide in an impartial manner. However, not all procedural guidelines necessarily violate both principles of natural justice in and of themselves. In order to make a choice as to which principle may be violated, it is crucial to examine the purpose of the guideline. In relation to Guideline 7, I will analyze next two purposes: procedural consistency and procedural expediency.

\subsection{Consistency and Expediency}

At first glance, procedural guidelines potentially impact to a lesser extent on the independence and impartiality of decision makers than substantive guidelines do. Admittedly, among all types of guidelines, substantive guidelines exert the greatest influence on the ability of a decision maker to decide according to their own conscience and opinion, because they are issued for the main purpose of fostering consistency of public authorities' decisions. However, we know since ConsolidatedBathurst and Tremblay that the purpose of procedural guidelines can also be to foster consistency and, therefore, can also illegally impinge on members' independence.

In Thamotharem, Justice Evans analyzed the validity of Guideline 7 through the lenses of independence of board members. He based his analysis on the teaching of
Consolidated-Bathurst and Tremblay because he saw some similarities of purposes of Guideline 7 and the full board meeting procedure. He viewed them both as policy instruments aiming at fostering consistency. If the purpose of Guideline 7 were truly to foster consistency, I would have agreed with Justice Evans's analysis, but my view is that such is not the case. The primary goal of Guideline 7 is to foster expediency of the RPD decision-making process.

Before going further into these explanations, a few words are necessary on the meanings of the concept of consistency. There are at least two meanings to the concept. The first meaning relates to a "thick" version of the concept; the second meaning, to a "thin" version. In its thick version, consistency refers to the principle "treat like cases alike." ${ }^{6}$ It is about logical coherence of substantive reasons bringing a decision maker to decide one way or another. The thick version is about the "what" and requires a decision maker to not be affected by his personal biases and preferences. In this thick sense "consistency" is considered to be an aspect of the rule of law. 57

In its thin version, consistency refers to the manner in which a case is decided: the procedure. Procedural consistency is about the "how" and is linked to fairness. The demand for fairness arises when there is a difference in the procedural treatment between cases. The demand is satisfied when the reasons that "justify a process that might end up treating cases differently even though their characteristic are the same." ${ }^{8}$ It is precisely to meet the demand for fairness that Guideline 7 includes paragraph 23. Recall that paragraph 23 allows a member to vary the order of questioning by permitting the claimant to present his case first if the claimant shows that his circumstances are exceptional. Save for exceptional circumstances, all cases are treated through the reverse order questioning procedure.

In this sense, Guideline 7 fosters consistency, but only the thin version of consistency. Indeed, before the Chairperson issued Guideline 7, the order of questioning was within the discretion of each RPD board member. As a result the order of questioning was not uniform among regions in Canada or among members within a region. Therefore, Guideline 7 aims at fostering consistency of the procedure followed by RPD members across Canada. Unlike the full board meeting procedure examined in the Supreme Court trilogy, Guideline 7 has no impact (or negligible impact) on fostering substantive consistency. Therefore, the issue as to whether Guideline 7 creates a reasonable apprehension of bias does not appear to be particularly relevant to resolve the issue as to its validity. Resorting to the reverse order of questioning does not clearly impede the ability of RPD members to decide according to their own conscience and opinion. It may have an impact on the quality of the decisions, but not because they are 
inconsistent (thick version), but because they were unfairly decided. On this point, all judges agreed that Guideline 7 was procedurally fair, but they also all agreed that violation of the principle of procedural fairness will be dealt with on a caseby-case basis.

However, this finding does not close the inquiry. Indeed, even if a procedural guideline does not violate the principles of natural justice or procedural fairness as found in case law, it can nonetheless be found invalid for incompatibility with the process established by the statute. A party contesting a guideline should demonstrate through legal interpretation that a guideline is not compatible with the statutory powers conferred to a board.

\section{Compatibility of Guideline 7 with the IRPA}

The Canadian Council for Refugees, intervening in Thamotharem and Benitez, raised the question as to whether Guideline 7 transformed the refugee determination process to such a point as to render it incompatible with the IRPA. None of the judges of the Federal Court of Appeal thought that Guideline 7 was incompatible with the IRPA, but no clear justifications were provided to support this statement. In this section, I will look at the compatibility of Guideline 7 with two provisions of the IRPA.

The first provision is s. $162(2) .{ }^{59}$ It confers a duty on each division of the IRB to "deal with all proceedings before it as informally and quickly as the circumstances and the considerations of fairness and natural justice permit." Thus, the question I will examine first is whether Guideline 7 maintains a balance between expediency and fairness. The second provision is s. $170 a) .{ }^{60}$ With it, the RPD had conferred upon it an explicit power to inquire with the promulgation of the IRPA. ${ }^{61}$ This grant of explicit power appears to be an unknown legal phenomenon in the realm of purely adjudicative tribunals. This engenders an interpretative problem since case law does not provide meaningful parameters to guide the interpretation of the scope of the power to inquire when used by this type of decentralized public authority. Therefore, the interpreter has to start anew. This is the task to which I will turn in section 4.2 of this paper.

In the following section, however, I will first present some of the arguments which could be made in support of the view that Guideline 7 raises concerns with respect to its compatibility with the IRPA. My goal is to show that a more detailed analysis of the compatibility of Guideline 7 with the IRPA would have been gained in being conducted in Thamotharem.

\subsection{Maintaining a Balance between Expediency and} Fairness

To answer the question as to whether Guideline 7 maintains a balance between expediency and fairness, a return to paragraph 23 of Guideline 7 is essential. This paragraph entitles a RPD member to vary the order of questioning when she is of the opinion that exceptional circumstances exist. To exemplify what the Chairperson means by exceptional circumstances, paragraph 23 speaks of cases involving a "severely disturbed claimant" or a "very young child." However, it is not at all clear that these "examples" are merely "examples." They can be construed as constituting strict categories of situations for which a member will agree to vary the order of questioning, to the exclusion of other types of situations. In order to make this point, one has to examine the interplay between two IRB guidelines: Guideline 7 and Guideline 8 Guideline on Procedures with Respect to Vulnerable Persons Appearing Before the Immigration and Refugee Board of Canada, ${ }^{62}$ which became effective in December 2006. The effect of Guideline 8 is to limit the scope of the application of Guideline 7 in two ways: (1) to obtain an order varying the order of questioning; (2) to confine its application to the two "examples" provided in paragraph 23.

With respect to the first point, Guideline 8 specifies to Board members that they can resort to a whole range of procedures, such as varying the order of questioning, to accommodate the specific vulnerability of a claimant. Varying the order of questioning is only one means among eight proposed to Board members in Guideline $8 .{ }^{63}$ Therefore, the application of paragraph 23 of Guideline 7 is only one possibility. And since paragraph 23 applies only to exceptional circumstances, it is reasonable to argue that Board members are implicitly required to grant an application to vary the order of questioning only after they examined other procedural accommodations laid down in Guideline 8.

With respect to the second point, Guideline 8 plays a significant role in the classification of refugee claims in terms of the degree of vulnerability of claimants. According to Guideline 8, there appear to be two levels of vulnerability: common and severe.

For the purposes of this Guideline, vulnerable persons are individuals whose ability to present their cases before the IRB is severely impaired. Such persons may include, but would not be limited to, the mentally ill, minors, the elderly, victims of torture, survivors of genocide and crimes against humanity, and women who have suffered gender-related persecution. ${ }^{64}$

This Guideline addresses difficulties which go beyond those that are common to most persons appearing before the IRB. It is intended to apply to individuals who face particular difficulty and who require special consideration in the procedural 
handling of their cases. It applies to the more severe cases of vulnerability. [Emphasis added] ${ }^{65}$

Given that Guideline 8 clearly applies only to "the more severe cases of vulnerability" (referring in this to the language used by paragraph 23 of Guideline 7) and that it is only in these cases that the possibility of varying the order of questioning is open to accommodate claimants, it becomes rather clear that paragraph 23 of Guideline 7 has no life in and of itself: its scope is meant to be construed in light of Guideline 8. Therefore, it is reasonable to argue that when Guideline 7 speaks of "severely disturbed claimant" as being merely an example of situation for which the order of questioning can by varied, it is inaccurate. It is a strict and exclusive category of cases (together with "the very young child" category) for which paragraph 23 can come into play. As a consequence, it is unlikely that RPD members retain any measure of meaningful discretion to determine if they will grant an order to vary the order of questioning in the case of a claimant not falling into either one of the two categories set by paragraph 23. From this interpretation, it appears that the only discretion they have left is to determine whether varying the order of questioning is the appropriate procedure to accommodate the specific vulnerability of a claimant.

On a final note, it is important to say that, for the moment, it is not possible to check the validity of this interpretation. Even if the IRB produced some forty decisions in Thamotharem to show how paragraph 23 is applied by RPD members, the decision of the Court does not provide specific information on these cases to enable scholars to conduct proper research. In addition, the IRB appears to be very reluctant to publish these decisions in the Quicklaw (QL) databank. Indeed, we found only a couple of RPD decisions in which the member agreed to vary the order of questioning. ${ }^{66}$ Although the panels agreed with the objection, their reasons were supposed to be found in an appendix to the decision, but were not made available through QL. As a result, there is no significant public information readily available on the parameters of the application of paragraph 23.

In sum, the interplay of Guidelines 7 and 8 raises the issue as to whether the creation of categories of claimants entitled to the procedural accommodation set out in paragraph 23 has the effect of favouring expeditiousness at the expense of fairness in determining claims for refugee status.

\subsection{The Scope of the Statutory Power to Inquire}

When a guideline is related to a specific statutory power, it is useful to first inquire as to the function of this guideline in relation to that power. Since I already developed this question in other papers, I will simply recall that a guideline can affect a legal system in different ways, such as delimiting its parameters by confining and structuring discretion, or by developing or by transforming it (at which point of course the legality of the guideline is clearly disputable). ${ }^{67}$ With respect to Guideline 7, the IRB claims that its function is to delimit the scope of the power to inquire. More specifically, the Board is of the opinion that the power to inquire means that RPD members can "define what issues must be resolved in order for them to render a decision." 68 The IRB feels confident that Guideline 7 is compatible with the IRPA. Justice Evans agreed with this view, but for another reason. His argument is that Guideline 7 is compatible with the IRPA procedural model created for the RPD, which he qualified as inquisitorial. In this section, I will bring counter argument to dispute both points of view. I will start with an examination of the qualification that the refugee determination process is "inquisitorial," and will move thereafter to an examination of the IRB interpretation of the scope of the power to inquire.

The nature of the refugee determination process intrigues many researchers and scholars (including those among the IRB itself) since, in its official documents, the Board sometimes refers to a "non-adversarial process" 69 and at other times to an "inquisitorial process"70 to qualify the decision making procedure of the RPD. The point is that there appears to be a difficulty in identifying the precise nature of the refugee determination process. It is clear that the claimant must discharge her burden of proof that she is a refugee or a person in need of protection. However, there is usually no opposite party to contest her claim or to check the truthfulness of her story. If the RPD member is of the opinion that the claim is not well-founded, he has to be somewhat entitled to challenge the claimant by inquiring into the claim, in order to ultimately make a determination according to his conscience and opinion. However, being able to inquire into a claim does not mean that the process is inquisitorial.

In common law (and civil law) an inquisitorial system is distinguished from an adversarial system. In an inquisitorial system, the judge has a prosecuting role. This procedure is characterized by the fact that all initiatives, from the first to the last day of the trial, are taken by the judge: the introduction of the instance, the direction of the trial, the gatherings of facts, and the assembling of the evidence. ${ }^{71}$ An adversarial process is characterized by a procedure in which the parties take, exclusively or principally, the initiatives of introducing the instance, its direction, and its instruction. ${ }^{72}$ Decision makers play no prosecutorial role: the function of judging and prosecuting are partitioned.

It is a given that the refugee determination process is not adversarial, but it is also legally inaccurate to speak of it as being inquisitorial. Board members do not prosecute refugee claimants: their role is not to find sufficient evidence to "make the Board's case" against a claimant. Beside its legal inaccuracy, the insistence on avoiding the word "inquisitorial" 
to qualify the RPD process is important for two additional reasons. First, it sends confusing signals to Board members, especially those without legal training. Second, and most importantly, an insistence on the inquisitorial nature of the IRB process may trigger questions as to its constitutional validity. Recall that the Supreme Court decided in Régie des permis d'alcool that impartiality requires separation of functions between that of a "prosecutor" and that of an "adjudicator" within a board. Although this decision was based on the Quebec Charter and applied in the context of a regulatory board, it can be argued that a lack of separation between these functions can raise a reasonable apprehension of bias. Therefore, great caution should be exercised when qualifying a process, especially one followed by a purely adjudicative tribunal. In the case of the RPD, the word "inquisitorial" to qualify the process should be clearly banished.

As for the qualification of non-adversarial, it is accurate but it only highlights the fact of no opposite party to contest the claim. My view is that the emphasis should be put on what truly distinguishes the RPD process from other processes generally followed by purely adjudicative tribunals: its power to inquire into a claim.

In fact, the RPD process sits between the inquisitorial and the adversarial processes. On the one hand, the claimant takes the initiative to introduce the instance and participate in the gathering of facts. On the other hand, Board members are responsible for the direction of the process (which is notably highlighted by Guideline 7), but they also gather facts and assemble the evidence. For these reasons, I propose to qualify the RPD process as "investigative."

This being said, however, it does not resolve the issue as to the proper interpretation of the scope of the power to inquire. It is precisely the scope of this power resting on RPD members' shoulders that is less clear. In other words, everybody agrees that the RPD has some active role to play in the proceedings, but the question is: what is exactly the scope of the inquiry power conferred on a decision maker acting in a purely adjudicative tribunal such as the RPD? In my research for some guidance on this point, I found two possible meanings.

In Quebec, the Administrative Justice Act sets the general procedural regime applicable to decisions made by boards exercising an adjudicative function. It enables decision makers to take measures to circumscribe the issues. ${ }^{74}$ Before the hearing, a board can call a case management conference or a pre-hearing conference in view of reaching an agreement with the parties on the direction of the instance. Issues such as the following can be determined through such agreement: defining the questions to be dealt with at the hearing, determining how the conduct of the proceeding may be simplified or accelerated and the hearing shortened, examin- ing the possibility for the parties of admitting certain facts or of proving them by means of sworn statements. This is also what Guideline 7 entitles RPD members to do, but with a significant difference. Recall that the IRB states in the Guideline that the power to inquire means that members can define what issues must be resolved in order for them to render a decision. A decision maker in charge of a case can determine alone what the issues are in a given case. He does have to reach an agreement with the claimant on this point. Indeed, even if the claimant or her representative can "notify the RPD as soon as possible of any issue it wants to add or delete, and explain why,"75 the decision maker does not have to agree with the content of the notification. He "can add or delete issues even during the course of the hearing."76

Therefore, the question becomes whether the explicit grant of a power to inquire to RPD members means that the IRB can go as far entitling them to decide alone what the issues at stake are. In other words, the question comes down to the participatory right of refugee claimants. Do they have a right to determine with the IRB members the issues at stake pertaining to their claim? What would be the legal foundation of such a right (the IRPA, explicitly or implicitly, or the common law)?

My intention is not to answer these questions in this paper for it would require a lengthy analysis. Indeed, a proper analysis of the factors set in the Baker case would need to be conducted first. ${ }^{77}$ Further, in-depth research on the scope and limit of the right to an oral hearing and the right to present evidence, inter alia, which are granted to refugee claimants in the IRPA, ${ }^{78}$ would be clearly relevant to such an analysis. Of course, this analysis would also need to be contextualized by taking into account the specific environment of the refugee determination process, being shaped by statute, regulations, and the relevant policies of the IRB applicable to the Refugee Protection Division to fix a given problem. ${ }^{79}$

\section{Conclusion}

In this paper, I have proposed an examination of the scope and limits of the doctrine of fettering discretion to assess the validity of guidelines. As currently applied, this doctrine does not provide a deep and nuanced understanding of the multi-faceted functions of guidelines and other policy instruments used by public authorities in contemporary administrative law. Courts have focused their inquiry on the mandatory character of the guideline. When facing substantive guidelines, this framework of analysis reveals important problems with them. However, when applied to procedural guidelines, this type of inquiry is not as useful because these guidelines, just as procedural rules, are not generally meant to be mandatory. 
My proposal is that the focus of the inquiry into the validity of a procedural guideline should be first on its compatibility with the decision making process established by statute, and in particular, with the procedural duties and powers granted to board members. In sum, the real issues are whether a guideline violates (1) the participatory rights of a claimant to a process or (2) the duty of Board members to decide independently and impartially.

Starting with the second ground (bias), the doctrine of "fettering the independence and impartiality" of board members, as enunciated by the Supreme Court in ConsolidatedBathurst, Tremblay and Ellis Don, and the Federal Court of Appeal in Thamotharem and Benitez, may be more or less relevant depending on the purpose of a procedural guideline. Indeed, procedural guidelines do not necessarily influence decision makers when they exercise their adjudicative function. Admittedly, those aiming at fostering substantive consistency ("treat like cases alike") of decisions do; those aiming at fostering procedural expediency ("justice delayed, justice denied") do not.

In the case of a guideline aiming at fostering procedural expediency, such as in Guideline 7, the examination of the effect of the guideline on the participatory rights of a claimant may prove to shed a more revealing light on the problems they may raise. In this case, it may be particularly relevant to ask oneself whether the guideline merely delimits (confines and structures) the procedural duties and powers of an administrative tribunal, or if it goes further and transforms the process, as the Canadian Council for Refugees submitted. In the future, courts could be asked to examine the issue as to whether claimants for refugee status have a right to define the issues at stake in their case and, if yes, whether Guideline 7 , especially in light of the IRB case management system, ${ }^{80}$ violates their participatory rights to the procedure.

Finally, closer attention should be paid to guidelines issued to enhance expediency of a decision making process. This type of guideline may pose a higher risk of violating the participatory right to the procedure than any other guideline (nature or purpose). In the case of a tribunal such as the IRB, the government of the day can exercise great pressure so that it increases the speed of its decisions to eliminate or reduce significantly a backlog for example. This goal is not in itself problematic: long delays in determining cases engender undesirable effects on the rights and interests of people as well as the legitimacy of a public institution. However, it remains a basic tenet of our legal system that expeditiousness should not overcome fairness. To keep this balance is crucial to maintain legitimacy and credibility of any decision making process.

\section{Notes}

1. For information on the IRB rules, see Immigration and Refugee Board, online: <http://www.irb-cisr.gc.ca/en/ references/policy/rules/index_e.htm> (date accessed: 7 May 2008). The Immigration and Refugee Protection Act, 2001, c. 27, s. 161(1) [IRPA], provides statutory authority for the rules. For information on policy instruments used by the IRB, see Immigration and Refugee Board, online: $<h t t p: / / w w w . i r b-c i s r . g c . c a / e n / r e f e r e n c e s / p o l i c y / i n d e x \_e$. $h t m>$ (date accessed 7 May 2008). See also on the same site the document entitled Policy Making in the Immigration and Refugee Board of Canada (February 2006), which explains the difference between the types of policy instruments used by the IRB.

2. Guideline 7 - Concerning Preparation and Conduct of a Hearing in the Refugee Protection Division (October 2003), IRB, online: <http://www.irb-cisr.gc.ca/en/references/ policy/guidelines/index_e.htm> (date accessed: 7 May 2008) [Guideline 7].

3. Thamotharem v. Canada (Minister of Citizenship and Immigration), [2007] A.C.F. no 734 (QL); [2007] F.C.A. 198; 60 Admin. L.R. (4th) 247 (Décary, Sharlow, and Evans JJ.A.), paras. 19-21 [Thamotharem cited to A.C.F.].

4. A Refugee Protection Officer (RPO) is a civil servant working for the IRB, whose role is to assist members in the preparation of cases before, during, and after the hearing when he is scheduled for a hearing.

5. Donald Galloway, "Proof and Narrative: Reproducing the Facts in Refugee Claims" (Manuscript produced for the conference Best Practices for Refugee Status Determination: Principles and Standards for State Responsibility, held at the Monash University Centre, Prato, Italy, 29-30 May 29-30 2008). In this article, Galloway is very critical of the use that the IRB makes of the Personal Information Form.

6. Guideline 7, supra note 2 at para. 23: "The member may vary the order of questioning in exceptional circumstances. For example, a severely disturbed claimant or a very young child might feel too intimidated by an unfamiliar examiner to be able to understand and properly answer questions [ ... ]."

7. Thamotharem v. Canada (Minister of Citizenship and Immigration), [2006] F.C.J. No. 8 (QL), [2006] FC 16, [2006] 3 F.C.R. 168 (Blanchard J.) [Thamotharem cited to F.C.J.].

8. Benitez v. Canada (Minister of Citizenship and Immigration), [2006] F.C.J. No. 631 (QL); [2006] FC 461; [2007] 1 F.C.R. 107 (Mosley J.) [Benitez cited to F.C.J.].

9. Thamotharem, supra note 3; Benitez v. Canada (Minister of Citizenship and Immigration), [2007] A.C.F. no 735 (QL); [2007] F.C.A. 199 (Evans, Décary, Sharlow JJ.A.) [Benitez cited to A.C.F.]. Justice Evans's reasons in Thamotharem also applied to Benitez: see Benitez at para. 7.

10. Daniel Thamotharem v. Minister of Citizenship and Immigration-and-Immigration and Refugee Board (F.C.) (Civil) (By Leave) (32185): Coram: Bastarache / Abella / Charron; Jorge Luis Restrepo Benitez v. Minister of Citizenship and 
Immigration-and-Immigration and Refugee Board (F.C.) (Civil) (By Leave) (32180) : Coram: Bastarache / Abella / Charron.

11. David Mullan, Administrative Law, $3^{\text {rd }}$ ed. (Toronto: Carswell, 1996) at para. 475; Baker v. Canada (Minister of Citizenship and Immigration), [1999] 2 S.C.R. 817 at para. 54 [Baker cited to S.C.R.].

12. Thamotharem, supra note 3 at para. 56; Ainsley Financial Corp. v. Ontario (Securities Commission) (1994), 121 D.L.R. $\left(4^{\text {th }}\right) 79$ (Ont. C.A.) at 83 [Ainsley cited to D.L.R.]. See Mullan, supra note 11 at para. 501; Martineau and al. v. The Matsqui Institution Inmate Disciplinary Board, [1978] 1 S.C.R. 118 at 129.

13. Peter Carver, "Guides' Honour: A Note on Procedural Guidelines and the Decisions in Thamotharem $v$. Canada (M.C.I.) and Benitez v. Canada (M.C.I)", (2006) Administrative Law Reports $\left(4^{\text {th }}\right) 279$.

14. Capital Cities Communications v. C.R.T.C., [1978] 2 S.C.R. 141 at 170 [Capital Cities Communications cited to S.C.R.].

15. Mullan, supra note 11 at paras. 479-481.

16. Maple Lodge Farms Ltd. v. Canada, [1982] 2 S.C.R. 2 [Maple Lodge cited to S.C.R.]; Ainsley, supra note 12.

17. For example, guidelines resembling those which have already been found invalid by courts, such as Ainsley, supra note 12; Dlugosz c. P.G. du Québec, [1987] R.J.Q. 2312 (C.A.).

18. Carver, supra note 13 at 289.

19. Ainsley Financial Corporation et al. v. Ontario Securities Commission et al. (1993) 14 O.R. (3d) 280 at paras. 46-53 (para. 46 states the criteria; 47-53 apply them). These criteria were referred to with approval by the Ontario Court of Appeal: Ainsley, supra note 12.

20. Ainsley, supra note 7 at 109 , cited in Thamotharem, supra note 7 at para. 112

21. See text of para. 23 of Guideline 7 in footnote 6 .

22. Thamotharem, supra note 7 at para. 119.

23. Benitez, supra note 8 at para. 166.

24. Thamotharem, supra note 3 at para. 54 .

25. Ibid. at para. 73 .

26. First, a qualitative research would need to be made. The sample of research would comprise, at the very least, the applications to vary the order of questioning and the decisions made for each application. The percentage of such applications in relation to the total number of decisions made on a yearly basis by the RPD (around 25,000) is unknown, but even if it were only 1 per cent of all decisions, it means that 250 files would need to be reviewed. This is a huge task that would require human and financial resources that are clearly beyond the means of counsels and refugee claimants. But this is not all. One other hurdle awaits the researcher. The IRB publishes only a selected and small portion of RPD decisions. To access the unpublished decisions, an access to information request must be filed which would take months for the IRB to process, to not mention the costs to do so.
27. Thamotharem, supra note 3 at para. 78 .

28. Ibid. at para. 74 .

29. Ibid. at para. 58 .

30. Roderick A. MacDonald, "Pour la reconnaissance d'une normativité juridique implicite et 'inférentielle," (1986) 1 Sociologie et Sociétés 47.

31. Thamotharem, supra note 3 at para. 65 .

32. See Martineau et al. v. The Matsqui Institution Inmate Disciplinary Board, [1978] 1 S.C.R. 118, 123 (Laskin J. dissenting).

33. Thamotharem, supra note 3 at paras. $66 \& 71$.

34. Ibid. at para. 104.

35. Refugee Protection Division Rules, SOR/2002-230.

36. Thamotharem, supra note 3 at para. 98 .

37. Ibid. at para. 85 [emphasis added].

38. Ibid. at paras. $86-87$.

39. Ibid. at para. 88 .

40. Ibid. at para. 96 .

41. IWA v. Consolidated-Bathurst Packaging Ltd., [1990] 1 S.C.R. 282; [1990] S.C.J. No. 20 (QL) [Consolidated-Bathurst cited to S.C.J.].

42. Thamotharem, supra note 7 at para. 134 .

43. Ibid. at para. 135 .

44. Benitez, supra note 8 at para. 167.

45. Thamotharem, supra note 7 at para. 169; Benitez, supra note 8 at para. 170 .

46. In addition, even if one accepts Justice Mosley's view that there was no evidence in the file to support the view that Guideline 7 fettered RPD members, my question is to which extent it would be possible to bring such evidence of threats and sanctions by the Chairperson to a court. Indeed, this type of evidence would not be divulged either by the IRB or members during their mandate and it is unlikely that record of it would be kept or that the Board would willingly give access to it. This evidence could probably be made by former RPD members (presuming that it would be possible to find former RPD members who would be disposed to testify) given the likelihood that their credibility and character would likely be sternly attacked by the Minister of Citizenship and Immigration or the IRB (after being allowed to intervene in the case).

47. Thamotharem, supra note 3 at para. 89 .

48. Ibid. at para. 88 .

49. Ibid. at para. 83 .

50. Canadian Pacific Ltd. v. Matsqui Indian Band, [1995] 1 S.C.R. 3 at para. 83.

51. Barreau de Montréal v. Québec (Procureure générale), [2001] R.J.Q. 2058 (Q.C.A.).

52. A purely adjudicative tribunal is the type of tribunal that resembles most a court and just like courts their function is to apply legal provisions. Therefore, they cannot base their decisions on the personal preferences of the government or the Chairperson, unless clear and express power is statutorily conferred to state those preferences through policy in- 
struments: Bell Canada v. Canadian Telephone Association Employees, [2003] 1 S.C.R. 884 at paras. 37-38.

53. Thamotharem, supra note 3 at para. 90; IRPA, supra note 1 , s. 159. (1).

54. Thamotharem, supra note 3 at para. 83 .

55. Canada, Immigration and Refugee Board, Guideline 4 Women Refugee Claimants Fearing Gender-Related Persecution (November 1996), online: <http://www.irb-cisr. gc.ca/en/references/policy/guidelines/women_e.htm> (date accessed: 2 July 2008).

56. David A. Strauss, "Must Like Cases be Treated Alike?" (Public Law and Legal Theory Working Paper no. 24, University of Chicago, 8 May 2002), online: <http://papers.ssrn.com/ sol3/papers.cfm?abstract_id=312180> (date accessed: 2 July 2008).

57. Ibid. at 18; Consolidated-Bathurst, supra note 41 at 47 (pdf electronic version).

58. Strauss, supra note 56 at 20.

59. The IRB refers expressly to this provision of the IRPA in the introduction of Guideline 7, supra note 2.

60. Ibid. in the section following the introduction.

61. IRPA, supra note 1, s. 170(a).

62. Guideline 8 - Guideline on Procedures with Respect to Vulnerable Persons Appearing Before the Immigration and Refugee Board of Canada (December 15, 2006), online: $<$ http://www.cisr-irb.gc.ca/en/references/policy/guidelines/vulnerable_e.htm\#1> (date accessed: 2 July 2008) [Guideline 8].

63. Ibid. at para. 4.2.

64. Ibid. at para. 2.1 .

65. Ibid. at para. 2.3 .

66. X.Z.A. (Re), [2007] R.P.D.D. No. 19 (QuickLaw, Panel: R. Dawson, July 11, 2007); F.F.I. (Re), [2005] R.P.D.D. No. 31 (QuickLaw. Panel: Steve Ellis, May 26, 2005); Wang v. Canada (Minister of Citizenship and Immigration), [2006] R.P.D.D. (QL), Panel: Steve Ellis, March 28, 2006. Research done up until 1 May 2008.

67. France Houle, "La lecture des blancs dans le droit et la validité des règles administratives : essai sur deux modèles issus du positivisme juridique," in Ysolde Gendreau, ed., Le lisible et l'illisible (Montréal: Les Éditions Thémis, 2003); France Houle \& Lorne Sossin, “Tribunals and Guidelines: Exploring the Relationship Between Fairness and Legitimacy in Administrative Decision-Making" (2006) 49:3 Canadian Public Administration 282.

68. Guideline 7, supra note 2 in the section following the introduction.

69. See, for example, Canada, Immigration and Refugee Board, CRDD Handbook, at para. 1.2.3.1, online: <http://www.irb- cisr.gc.ca/en/references/legal/rpd/handbook/handbook_e. pdf $>$ (date accessed: 2 July 2008) [CRDD Handbook].

70. See, for example, Canada, Immigration and Refugee Board, IRB News, online: <http://www.irb-cisr.gc.ca/en/about/ publications/irbnews/2004/issue01_e.pdf> (date accessed: 2 July 2008).

71. Juriterm Plus: banque terminologique de la common law, Université Moncton, Centre de traduction et de terminologie juridique, s.v. "système inquisitoire" (electronic resource), online: <http//www5.umoncton.ca/cttj/juriterm. dll/EXEC> (date accessed: 5 December 2008).

72. Ibid., s.v. "système accusatoire."

73. Ibid., s.v. "investigation": an investigation is an "inquiry, judicial or otherwise, for the discovery and collection of facts concerning a certain matter or matters."

74. An Act Respecting Administrative Justice, R.S.Q., c. J-3, s. 12.

75. Guideline 7, supra note 2 at para. 1.1.2.

76. Ibid. at para. 18.

77. Baker, supra note 11 at paras. 23-28. L'Heureux-Dubé J. proposed five factors: (1) the nature of the decision being made and process followed in making it; (2) the nature of the statutory scheme and the terms of the statute pursuant to which the body operates; (3) the importance of the decision to the individual or individuals affected; (4) the legitimate expectations of the person challenging the decision; (5) the choices of procedure made by the agency itself.

78. IRPA, supra note 1 , section $170 b$ ) and $e$ ).

79. For examples, the case management system established through policies would be worth looking at: Canada, Immigration and Refugee Board, Fast Track Policy: Expedited Process (March 2005), online: <http://www.irb-cisr.gc.ca/ en/references/policy/policies/exprocess_e.htm> (date accessed: 2 July 2008); Canada, Immigration and Refugee Board, Policy on Oral Decisions and Oral Reasons (September 10, 2003), online: <http://www.irb-cisr.gc.ca/en/references/policy/policies/oral_e.htm> (date accessed: 2 July 2008).

80. Ibid.

France Houle has been a professor at the University of Montreal, where she teaches administrative law, since 1999. She is a member of the Research Centre on Globalization and Work, where she is developing a research program on migrant labour and public governance. 